\title{
Synthesis and crystal structures of cis-palladium(II) and cis-platinum(II) complexes containing dipyridyl ligands
}

\author{
Noemí Andrade-López ${ }^{*}$ José G. Alvarado-Rodríguez, Simplicio González-Montiel, \\ María Elena Páez-Hernández, Carlos Andrés Galán-Vidal, and Araceli Jiménez-Pérez \\ Centro de Investigaciones Químicas. Universidad Autónoma del Estado de Hidalgo, Ciudad \\ Universitaria, Carretera Pachuca-Tulancingo Km. 4.5. Colonia Carboneras, Mineral de la \\ Reforma. C. P. 42184, México \\ E-mail:nandrade@uaeh.edu.mx
}

\section{Dedicated to Professor Rosalinda Contreras Theurel, an exceptional researcher}

\begin{abstract}
Coordinative behavior of the di-(2-pyridyl)hydroxymethane (1) and di-(2-pyridyl)-2pyridylsulfanylmethane (2) ligands towards $\mathrm{Pd}(\mathrm{II})$ and $\mathrm{Pt}(\mathrm{II})$ is described. The compounds 3-5 were characterized by IR, mass spectrometry and NMR spectroscopy. Crystal structures of $\left[\mathrm{Pt}\left\{\left(\mathrm{C}_{5} \mathrm{H}_{4} \mathrm{~N}\right)_{2} \mathrm{CH}(\mathrm{OH})\right\} \mathrm{Cl}_{2}\right] \quad 3$ and $\left[\mathrm{Pd}\left\{\left(\mathrm{C}_{5} \mathrm{H}_{4} \mathrm{~N}\right)_{2} \mathrm{CH}\left(2-\mathrm{C}_{5} \mathrm{H}_{4} \mathrm{NS}\right)\right\} \mathrm{Cl}_{2}\right] \mathbf{4}$ as DMSO solvates displayed the formation of neutral mononuclear complexes. In the complexes $\mathbf{3}$ and $\mathbf{4}$ is observed the formation of six-membered chelate rings. The local geometry of the metallic atoms can be described as square planar in the title complexes.
\end{abstract}

Keywords: $\mathrm{Pd}(\mathrm{II})$ and $\mathrm{Pt}(\mathrm{II})$ complexes, di-(2-pyridyl)-2-pyridylsulfanylmethane, di-(2pyridyl)hydroxymethane, NMR, $\mathrm{X}$ ray diffraction

\section{Introduction}

Several nitrogenated heterocyclic compounds as dipyridines have been widely used in coordination chemistry. ${ }^{1-6}$ These compounds act as versatile ligands towards transition metals which yield five- and six-membered chelate rings in a bidentate coordination mode ${ }^{7-16}$ Synthesis of compounds containing five-membered rings can be envisaged by the use of bipyridine (unbridged) derivatives (Ia, Figure 1). ${ }^{7,8}$ When the dipyridinic ligands have flexible bridging groups as methylene, hydroxymethyl, amine, hydrazone and amide groups, they mainly form sixmembered rings (Ib). ${ }^{9-16}$ In other dipyridines with less flexible bridging groups, the formation of five-membered rings (Ic) has been reported. ${ }^{17,} 18$ Recently, we described the synthesis of complexes of $\mathrm{Li}(\mathrm{I})^{19}$ and $\mathrm{Pd}(\mathrm{II})^{20}$ and the formation of five-membered rings by the use of the di(2-pyridyl)- $\underline{N}$-methylimine ligand; the formation of these rings has been attributed to the rigidity 
of the $\mathrm{C}=\mathrm{N}$ iminic bond. Continuing with our research, here we report the coordinative behavior of the flexible dipyridines $\mathbf{1}$ and $\mathbf{2}$ towards heavier tenth group Pd(II) and Pt(II) metals. Synthesis and characterization by NMR spectroscopy, mass spectrometry and IR of cis-dichloro[di-(2pyridyl)hydroxymethane)]platinum(II) $\quad \mathbf{3}$ and cis-dichloro-[di-(2-pyridyl)-2pyridylsulfanylmethane]palladium(II) $\quad \mathbf{4}$ and cis-dichloro-[di-(2-pyridyl)-2pyridylsulfanylmethane]platinum(II) 5 complexes are described. Crystal structures of the DMSO solvates 3 and 4 are reported.<smiles></smiles>

la<smiles></smiles>

$\mathrm{G}=\mathrm{CH}_{2}, \mathrm{C}(\mathrm{OH}) \mathrm{OCH}_{3}, \mathrm{NC}(\mathrm{O}) \mathrm{CH}_{3}, \mathrm{NH}$

$\mathrm{lb}$<smiles>CCCCCCCNC(=O)NN=O</smiles>

Figure 1. Complexes containing five- and six-membered chelate rings derived from dipyridines.

\section{Results and Discussion}

\section{Synthesis of ligands 1 and 2}

Di-(2-pyridyl)hydroxymethane 1 was synthesized from the reduction of the di-(2pyridyl)ketone. ${ }^{21} \mathrm{Di}$-(2-pyridyl)-2-pyridylsulfanylmethane 2 was prepared from the reaction of di-(pyridyl)chloromethane ${ }^{21}$ with 2-mercaptopyridine in equimolar ratio, see Scheme 1. 


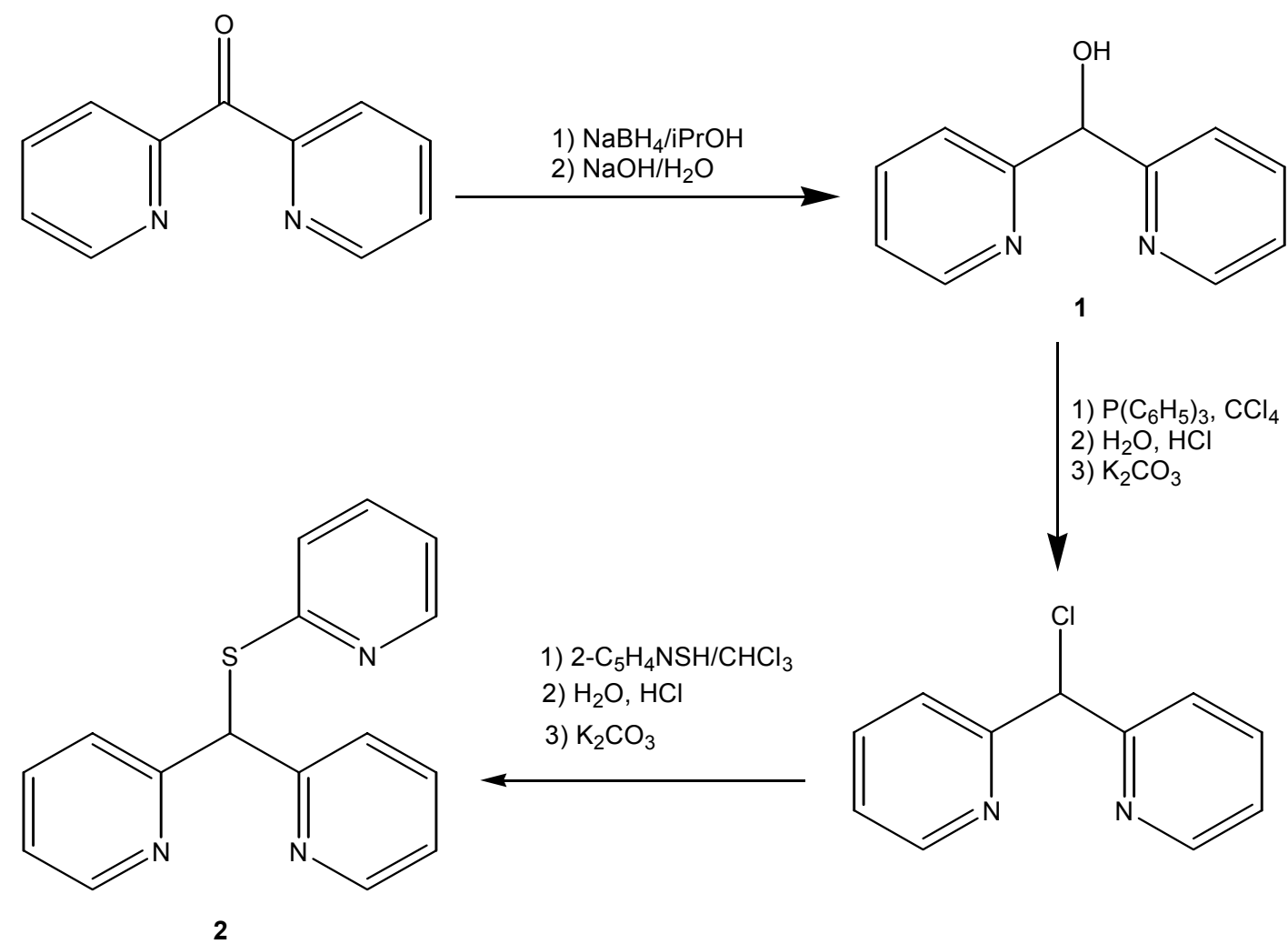

Scheme 1. Synthesis of ligands 1 and 2.

\section{Synthesis of palladium(II) and platinum(II) complexes 3-5}

Complexes 3-5 were synthesized from the reaction of $\mathbf{1}$ and $\mathbf{2}$ with $\mathrm{PdCl}_{2}$ or $\mathrm{PtCl}_{2}$ in equimolar ratio in hot acetonitrile, see Scheme 2.

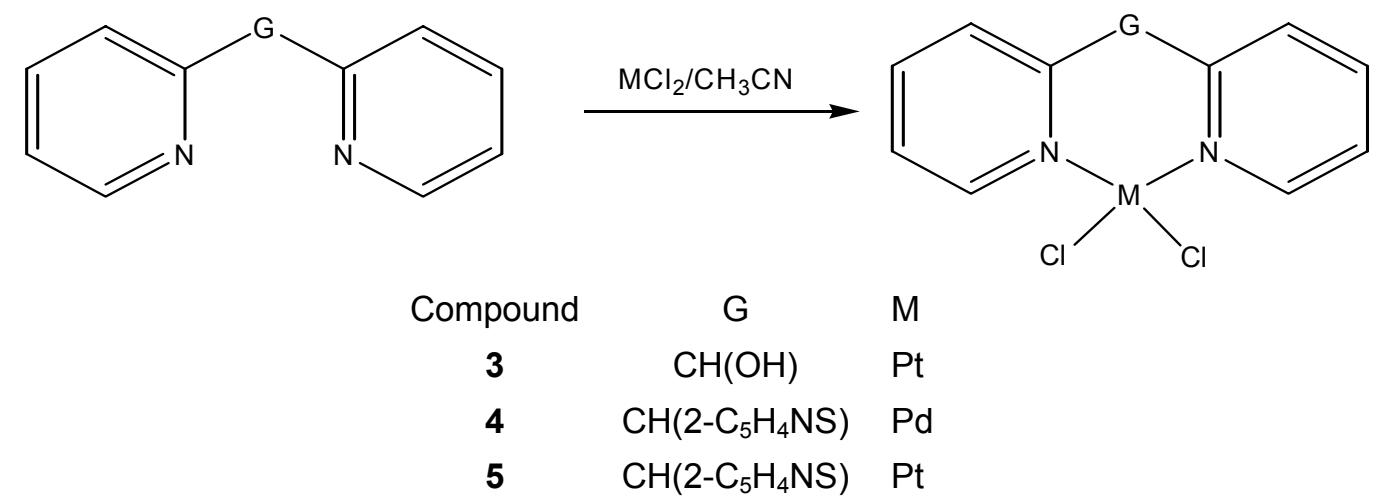

Scheme 2. Synthesis of the cis-dichloro complexes 3-5.

\section{NMR Spectra}

${ }^{1} \mathrm{H}$ and ${ }^{13} \mathrm{C}$ NMR data and the atom numbering for compounds $2,3,4$ and $\mathbf{5}$ are showed in Table 1 . 
Table 1. ${ }^{1} \mathrm{H}$ and ${ }^{13} \mathrm{C}\left\{{ }^{1} \mathrm{H}\right\}$ NMR data of compounds $2-5$ at about $20^{\circ} \mathrm{C}$

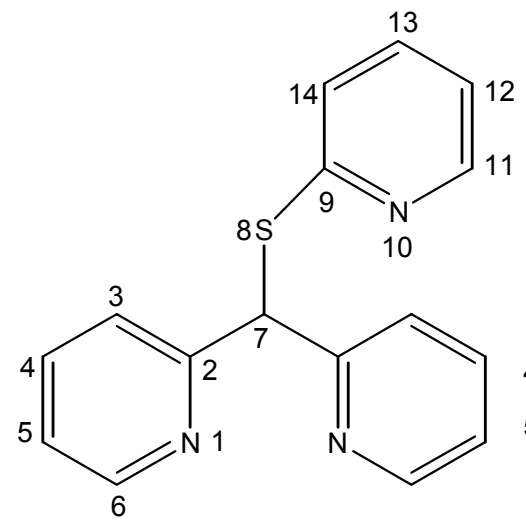

2

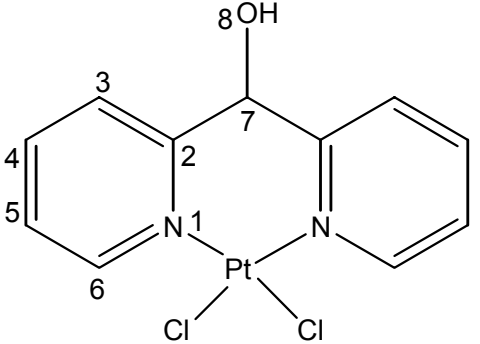

3<smiles></smiles>

$4 \mathrm{M}=\mathrm{Pd}$

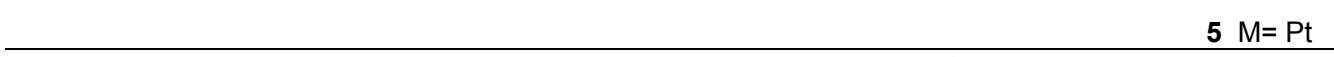

\begin{tabular}{|c|c|c|c|}
\hline Compound & Solvent & $\begin{array}{l}{ }^{1} \mathrm{H} \text { Chemical } \\
\text { Shift (ppm) }\end{array}$ & $\begin{array}{c}{ }^{13} \mathrm{C} \text { Chemical } \\
\text { shift (ppm) }\end{array}$ \\
\hline \multirow[t]{22}{*}{$2\left(\mathrm{C}_{5} \mathrm{H}_{4} \mathrm{~N}\right)_{2}-\mathrm{CH}-2-\mathrm{SC}_{5} \mathrm{H}_{4} \mathrm{~N}$} & $\mathrm{CDCl}_{3}$ & $8.51(\mathrm{~d}, 2 \mathrm{H}, J=4.76 \mathrm{~Hz} ; \mathrm{H} 6)$ & $158.5(\mathrm{C} 2)$ \\
\hline & & $8.31(\mathrm{~d}, 1 \mathrm{H}, J=4.76 \mathrm{~Hz} ; \mathrm{H} 11)$ & 157.9 (C9) \\
\hline & & $7.84(\mathrm{~d}, 2 \mathrm{H}, J=7.68 \mathrm{~Hz} ; \mathrm{H} 3)$ & $149.6(\mathrm{C} 11)$ \\
\hline & & $7.68(\mathrm{dd}, 2 \mathrm{H}, J=7.68,6.24 \mathrm{~Hz} ; \mathrm{H} 4)$ & $147.6(\mathrm{C} 6)$ \\
\hline & & $7.39(\mathrm{dd}, 1 \mathrm{H}, \mathrm{J}=7.68,7.00 \mathrm{~Hz} ; \mathrm{H} 13)$ & $138.6(\mathrm{C} 4)$ \\
\hline & & $7.19(\mathrm{dd}, 2 \mathrm{H}, J=6.24,4.76 \mathrm{~Hz} ; \mathrm{H} 5)$ & $136.3(\mathrm{C} 13)$ \\
\hline & & $7.14(\mathrm{~d}, 1 \mathrm{H}, J=7.68 \mathrm{~Hz} ; \mathrm{H} 14)$ & $124.3(\mathrm{C} 3)$ \\
\hline & & $6.87(\mathrm{dd}, 1 \mathrm{H}, J=6.96,4.76 \mathrm{~Hz}$; H12) & $122.9(\mathrm{C} 5)$ \\
\hline & & $6.71(\mathrm{~s}, 1 \mathrm{H}, \mathrm{H} 7)$ & $121.9(\mathrm{C} 14)$ \\
\hline & & & $120.0(\mathrm{C} 12)$ \\
\hline & & & $53.9(\mathrm{C} 7)$ \\
\hline & $\mathrm{DMSO}_{-d 6}$ & $8.47(2 \mathrm{H}, \mathrm{H} 6)$ & $158.0(\mathrm{C} 2)$ \\
\hline & & $8.29(1 \mathrm{H}, \mathrm{H} 11)$ & $156.8(\mathrm{C} 9)$ \\
\hline & & $7.93(2 \mathrm{H}, \mathrm{H} 3)$ & $150.0(\mathrm{C} 11)$ \\
\hline & & $7.77(2 \mathrm{H}, \mathrm{H} 4)$ & $148.4(\mathrm{C} 6)$ \\
\hline & & $7.65(1 \mathrm{H}, \mathrm{H} 13)$ & $139.5(\mathrm{C} 4)$ \\
\hline & & 7.34 (3H, H5, H14) & $137.7(\mathrm{C} 13)$ \\
\hline & & $7.07(1 \mathrm{H}, \mathrm{H} 12)$ & $124.2(\mathrm{C} 3)$ \\
\hline & & $6.47(1 \mathrm{H}, \mathrm{H} 7)$ & $123.9(\mathrm{C} 5)$ \\
\hline & & & $122.6(\mathrm{C} 14)$ \\
\hline & & & $121.1(\mathrm{C} 12)$ \\
\hline & & & $54.2(\mathrm{C} 7)$ \\
\hline
\end{tabular}




\begin{tabular}{|c|c|c|c|}
\hline \multirow[t]{6}{*}{$3\left[\mathrm{Pt}\left\{\left(\mathrm{C}_{5} \mathrm{H}_{4} \mathrm{~N}\right)_{2} \mathrm{CH}(\mathrm{OH})\right\} \mathrm{Cl}_{2}\right]$} & \multirow[t]{6}{*}{$\mathrm{DMSO}_{-d \sigma}$} & $8.92(\mathrm{~d}, 2 \mathrm{H}, J=5.12 \mathrm{~Hz} ; \mathrm{H} 6)$ & $157.7(\mathrm{C} 2)$ \\
\hline & & $8.15(\mathrm{dd}, 2 \mathrm{H}, J=7.72,7.52 \mathrm{~Hz} ; \mathrm{H} 4)$ & $153.2(\mathrm{C} 6)$ \\
\hline & & $7.95(\mathrm{~d}, 1 \mathrm{H}, J=5.12 \mathrm{~Hz} ; \mathrm{OH})$ & $141.0(\mathrm{C} 4)$ \\
\hline & & $7.85(\mathrm{~d}, 2 \mathrm{H}, J=7.72 \mathrm{~Hz} ; \mathrm{H} 3)$ & $125.8(\mathrm{C} 5)$ \\
\hline & & $7.50(\mathrm{dd}, 2 \mathrm{H}, J=7.52,5.12 \mathrm{~Hz} ; \mathrm{H} 5)$ & $122.2(\mathrm{C} 3)$ \\
\hline & & $6.37(\mathrm{~d}, 1 \mathrm{H}, J=5.12 \mathrm{~Hz} ; \mathrm{H7})$ & $74.4(\mathrm{C} 7)$ \\
\hline \multirow[t]{11}{*}{$4\left[\mathrm{Pd}\left\{\left(\mathrm{C}_{5} \mathrm{H}_{4} \mathrm{~N}\right)_{2} \mathrm{CH}\left(2-\mathrm{SC}_{5} \mathrm{H}_{4} \mathrm{~N}\right)\right\} \mathrm{Cl}_{2}\right]$} & \multirow[t]{11}{*}{$\mathrm{DMSO}_{-d \sigma}$} & $8.92(\mathrm{~d}, 2 \mathrm{H}, J=5.48 \mathrm{~Hz} ; \mathrm{H} 6)$ & $155.6(\mathrm{C} 9)$ \\
\hline & & $8.61(\mathrm{~d}, 1 \mathrm{H}, J=4.76 \mathrm{~Hz} ; \mathrm{H} 11)$ & $154.3(\mathrm{C} 2)$ \\
\hline & & $8.11(\mathrm{dd}, 2 \mathrm{H}, J=7.72,6.60 \mathrm{~Hz} ; \mathrm{H} 4)$ & $154.2(\mathrm{C} 6)$ \\
\hline & & $8.05(\mathrm{~d}, 2 \mathrm{H}, J=7.72 \mathrm{~Hz} ; \mathrm{H} 3)$ & $150.2(\mathrm{C} 11)$ \\
\hline & & 7.77 (dd, 1H, $J=7.72,7.68 \mathrm{~Hz} ; \mathrm{H} 13)$ & $141.3(\mathrm{C} 4)$ \\
\hline & & 7.55 (m, 3H, H5, H14) & $138.2(\mathrm{C} 13)$ \\
\hline & & $7.26(\mathrm{dd}, 1 \mathrm{H}, J=4.76,7.68 \mathrm{~Hz} ; \mathrm{H} 12)$ & $126.7(\mathrm{C} 3)$ \\
\hline & & $6.95(\mathrm{~s}, 1 \mathrm{H}, \mathrm{H} 7)$ & $125.6(\mathrm{C} 5)$ \\
\hline & & & $122.9(\mathrm{C} 14)$ \\
\hline & & & $121.8(\mathrm{C} 12)$ \\
\hline & & & $54.4(\mathrm{C} 7)$ \\
\hline \multirow[t]{11}{*}{$5\left[\mathrm{Pt}\left\{\left(\mathrm{C}_{5} \mathrm{H}_{4} \mathrm{~N}\right)_{2} \mathrm{CH}\left(2-\mathrm{SC}_{5} \mathrm{H}_{4} \mathrm{~N}\right)\right\} \mathrm{Cl}_{2}\right]$} & \multirow[t]{11}{*}{$\mathrm{DMSO}_{-d \sigma}$} & $9.03(\mathrm{~d}, 2 \mathrm{H}, J=5.84 \mathrm{~Hz} ; \mathrm{H} 6)$ & $155.2(\mathrm{C} 9)$ \\
\hline & & $8.62(\mathrm{~d}, 1 \mathrm{H}, J=4.40 \mathrm{~Hz} ; \mathrm{H} 11)$ & $154.8(\mathrm{C} 6)$ \\
\hline & & $8.13(\mathrm{dd}, 2 \mathrm{H}, J=7.72,7.68 \mathrm{~Hz} ; \mathrm{H} 4)$ & $154.0(\mathrm{C} 2)$ \\
\hline & & $8.02(\mathrm{~d}, 2 \mathrm{H}, J=7.72 \mathrm{~Hz} ; \mathrm{H} 3)$ & $150.1(\mathrm{C} 11)$ \\
\hline & & $7.71(\mathrm{dd}, 1 \mathrm{H}, J=7.90,7.68 \mathrm{~Hz} ; \mathrm{H} 13)$ & $141.1(\mathrm{C} 4)$ \\
\hline & & 7.54(dd, $2 \mathrm{H}, J=7.68 \mathrm{~Hz}, 5.88 \mathrm{~Hz} ; \mathrm{H} 5)$ & $138.4(\mathrm{C} 13)$ \\
\hline & & 7.47 (d, 1H, J= 7.90, Hz; H14) & $126.4(\mathrm{C} 3)$ \\
\hline & & $7.24(\mathrm{dd}, 1 \mathrm{H}, J=7.68 \mathrm{~Hz}, 4.40 \mathrm{~Hz} ; \mathrm{H} 12)$ & $126.1(\mathrm{C} 5)$ \\
\hline & & $6.93(\mathrm{~s}, 1 \mathrm{H}, \mathrm{H} 7)$ & $122.3(\mathrm{C} 14)$ \\
\hline & & & $121.7(\mathrm{C} 12)$ \\
\hline & & & $54.1(\mathrm{C} 7)$ \\
\hline
\end{tabular}

${ }^{1} \mathrm{H}$ NMR spectrum in $\mathrm{DMSO}_{-d 6}$ solution of 2 showed seven signals in the 8.47-7.07 ppm region and a singlet at lower frequency $(6.47 \mathrm{ppm})$ for the proton of the $\mathrm{CH}$ group, see Table 1 . In this ligand, the $\mathrm{H} 3-\mathrm{H} 6$ and $\mathrm{H} 11-\mathrm{H} 14$ protons were observed in a $2: 1$ ratio. Its ${ }^{13} \mathrm{C}\left\{{ }^{1} \mathrm{H}\right\}$ spectrum showed ten signals for the pyridine rings; the bridging $\mathrm{C} 7$ atom was observed at 54.2 ppm. Complexes 3, 4 and $\mathbf{5}$ are slightly soluble in acetonitrile and dimethylsulfoxide and insoluble in chloroform and benzene. ${ }^{1} \mathrm{H}$ spectra in DMSO-d6 solutions for 3, 4 and $\mathbf{5}$ showed four, seven and eight signals corresponding to the pyridine ring protons, respectively. In $\mathbf{4}$ and $\mathbf{5}$, the signal intensities for the di-2-pyridylmethyl and the 2-pyridylsulfanyl fragment protons were 
observed in a 2:1 ratio, as in the compound 2. In $\mathbf{3}$, the $\mathrm{OH}$ and $\mathrm{H} 7$ protons were observed as doublets at 7.95 and $6.37 \mathrm{ppm}$, respectively, whereas the $\mathrm{H} 7$ proton of the $\mathrm{CH}$ bridging group in 4 and 5 was observed as a singlet at 6.95 and $6.93 \mathrm{ppm}$, respectively, Table $1 .{ }^{1} \mathrm{H}$ NMR spectra of complexes 3-5 did not show significant variations in the chemical shift with respect to the free ligands 1 and 2.

On the other hand, ${ }^{13} \mathrm{C}\left\{{ }^{1} \mathrm{H}\right\}$ spectrum of complex 3 showed five signals for the pyridine rings and the spectra of $\mathbf{4}$ and $\mathbf{5}$ displayed ten signals. The bridging $\mathrm{C} 7$ carbon in the complexes $\mathbf{3}, \mathbf{4}$ and 5 was observed at $74.4,54.4$ and $54.1 \mathrm{ppm}$, respectively. In these complexes, the metallic coordination affects mainly the chemical shifts of the neighboring carbon atoms to the coordinate nitrogen atoms (C2 is shielded and C6 is deshielded).

The comparison of ${ }^{1} \mathrm{H}$ and ${ }^{13} \mathrm{C}$ NMR data indicates that the complexes $\mathbf{4}$ and $\mathbf{5}$ have analogous structures, where the palladium(II) and platinum(II) cations cause similar chemical shifts. The same situation occurs when the NMR spectra of complex $\mathbf{3}$ are compared with those of the palladium(II) analogue. ${ }^{20}$ These data and the magnetic equivalence of the pyridine rings of the dipyridine fragment suggest the formation of symmetrical palladium and platinum complexes with six-membered chelate rings.

\section{X-ray crystallography}

The structures in crystalline solid state of compounds $\mathbf{3}$ and $\mathbf{4}$ were determined by single-crystal X-ray diffraction analyses; they crystallized as DMSO solvates. Crystallographic data are given in Table 2 and selected bond lengths and angles are given in Table 3.

Molecular structures of complexes 3·DMSO and 4·DMSO are showed in Figures 2 and 3.

The X-ray structures of $3 \cdot \mathrm{DMSO}$ and $4 \cdot \mathrm{DMSO}$ showed that the pseudo-anthracenic tricyclic systems are not planar; the angles between the pyridine rings are $110.9^{\circ}$ and $123.5^{\circ}$ for $\mathbf{3}$ and $\mathbf{4}$, respectively. When the ligands 1 and $\mathbf{2}$ coordinate to the M(II) central atom, they behave as bidentate ligands, and leave the hydroxyl and 2-pyridylsulfanyl groups uncoordinated. In both complexes, the chelate ring is six membered, as proposed by the NMR analyses, and the local geometry of the $\mathrm{M}(\mathrm{II})$ central atom is square planar. 
Table 2. Selected crystallographic data for complexes $3 \cdot \mathrm{DMSO}$ and $4 \cdot \mathrm{DMSO}$

\begin{tabular}{|c|c|c|}
\hline Compound & 3·DMSO & $4 \cdot \mathrm{DMSO}$ \\
\hline Molecular Formula & $\mathrm{C}_{13} \mathrm{H}_{16} \mathrm{Cl}_{2} \mathrm{~N}_{2} \mathrm{O}_{2} \mathrm{PtS}$ & $\mathrm{C}_{18} \mathrm{H}_{19} \mathrm{Cl}_{2} \mathrm{~N}_{3} \mathrm{OPdS}_{2}$ \\
\hline$M_{\mathrm{r}}[\mathrm{g} / \mathrm{mol}]$ & 530.33 & 534.78 \\
\hline Crystal size $[\mathrm{mm}]$ & $0.58 \times 0.35 \times 0.23$ & $0.33 \times 0.30 \times 0.12$ \\
\hline $\mathrm{F}(000)$ & 504 & 536 \\
\hline Crystal system & Triclinic & Triclinic \\
\hline Space group & Plbar & Plbar \\
\hline$a[\AA]$ & $9.7309(9)$ & $8.2035(8)$ \\
\hline$b[\AA]$ & $10.0992(9)$ & $8.5934(8)$ \\
\hline$c[\AA]$ & $10.9146(10)$ & $15.5817(15)$ \\
\hline$\alpha\left[^{\circ}\right]$ & $65.232(2)$ & $76.956(2)$ \\
\hline$\beta\left[^{\circ}\right]$ & $89.001(2)$ & $81.603(2)$ \\
\hline$\gamma\left[^{\circ}\right]$ & $61.555(2)$ & $85.196(2)$ \\
\hline $\mathrm{V}\left[\AA^{3}\right]$ & $833.80(13)$ & $1057.16(18)$ \\
\hline Z & 2 & 2 \\
\hline$\rho_{\text {calcd. }}\left[\mathrm{Mg} / \mathrm{m}^{3}\right]$ & 2.112 & 1.680 \\
\hline$\mu\left[\mathrm{mm}^{-1}\right]$ & 8.863 & 1.341 \\
\hline GoF & 1.094 & 1.090 \\
\hline Temperature $[\mathrm{K}]$ & $298(2)$ & $298(2)$ \\
\hline$\theta$ range $\left[{ }^{\circ}\right]$ & 2.11 to 26.01 & 1.35 to 26.04 \\
\hline Reflections collected & 10132 & 13067 \\
\hline Unique reflections & 3278 & 4164 \\
\hline Absorption correction & SADABS & SADABS \\
\hline Solution method & Patterson & Patterson \\
\hline$R_{\text {int }}$ & 0.0286 & 0.0392 \\
\hline$R 1 ; \mathrm{wR} 2[\mathrm{I}>2 \operatorname{sigma}(\mathrm{I})]$ & $0.0216,0.0556$ & $0.0353,0.0818$ \\
\hline$R 1 ; \mathrm{wR} 2$ [all data] & $0.0242,0.0565$ & $0.0514,0.0976$ \\
\hline Largest residuals $\left[e \bullet \AA^{-3}\right]$ & $0.543 /-0.765$ & $0.553 /-0.348$ \\
\hline
\end{tabular}

As can be observed from the listed data in Table 3, the N-M(II) distances in these compounds are essentially the same and similar to other previously reported for dipyridine and pyridine complexes containing N-M bonds ( $\mathrm{M}=\mathrm{Pd}, \mathrm{Pt}){ }^{2}, 4,11,14,22,23$ The close similitude of the Pt-Cl and $\mathrm{Pd}-\mathrm{Cl}$ bond distances in complexes $\mathbf{3}$ and $\mathbf{4}$ can be attributed to the lanthanide contraction effect present in the $5 \mathrm{~d}$ platinum(II) cation.

With regard to the conformational features displayed by the complexes 3 and $\mathbf{4}$ where sixmembered chelate rings were formed, the central ring in both complexes is in a boat conformation. The position of the exocyclic ligands attached to the bridging carbon that joins the two pyridine rings deserves a more detailed discussion. The predominant conformers in solid state display the -OH group in $\mathbf{3}$ in a bowsprit position, as in the palladium analogue, ${ }^{20}$ and the - 
$\mathrm{SC}_{5} \mathrm{H}_{4} \mathrm{~N}$ group in 4 in a flagpole position. This difference can be attributable to an intramolecular contact between the soft acid palladium and the soft base sulfur ( $\mathrm{Pd}---\mathrm{S}=3.054 \AA$ ) that is shorter than the van der Waals radii sum $\left(\Sigma \mathrm{r}_{\mathrm{vdW}}(\mathrm{Pd}, \mathrm{S})=3.43 \AA\right)$ but longer than the covalent radii sum $\left(\Sigma \mathrm{r}_{\mathrm{cov}}(\mathrm{Pd}, \mathrm{S})=2.33 \AA\right) .{ }^{24}$ This interaction can be also responsible of the large folding in the tricyclic system observed in the complex 4 (interplanar angle $123.5^{\circ}$ in 4 respect to $110.9^{\circ}$ in 3 ).

Table 3. Selected bond lengths $[\AA]$ and bond angles $\left[{ }^{\circ}\right]$ of complexes

$\underline{\left.\mathrm{M}\left\{\left(\mathrm{C}_{5} \mathrm{H}_{4} \mathrm{~N}\right)_{2} \mathrm{G}\right\} \mathrm{Cl}_{2}\right] \cdot \mathrm{DMSO}}$

\begin{tabular}{lcc}
\hline Compound & 3·DMSO & 4·DMSO \\
\hline & $\mathrm{M}=\mathrm{Pt}$, & $\mathrm{M}=\mathrm{Pd}$, \\
$\mathrm{G}=\mathrm{CH}(\mathrm{OH})$ & $\mathrm{G}=\mathrm{CH}\left(\mathrm{SC}_{5} \mathrm{H}_{4} \mathrm{~N}\right)$ \\
$\mathrm{M}-\mathrm{Cl}(1)$ & $2.3020(12)$ & $2.3003(11)$ \\
$\mathrm{M}-\mathrm{Cl}(2)$ & $2.2962(12)$ & $2.3037(11)$ \\
$\mathrm{M}-\mathrm{N}(1)$ & $2.026(3)$ & $2.036(3)$ \\
$\mathrm{M}-\mathrm{N}(2)$ & $2.015(3)$ & $2.034(3)$ \\
$\mathrm{C}(11)-\mathrm{Y}(1)^{\mathrm{a}}$ & $1.401(5)$ & $1.838(4)$ \\
$\mathrm{Cl}(1)-\mathrm{M}-\mathrm{Cl}(2)$ & $91.03(5)$ & $92.25(4)$ \\
$\mathrm{N}(1)-\mathrm{M}-\mathrm{N}(2)$ & $86.76(13)$ & $87.76(12)$ \\
$\mathrm{Cl}(1)-\mathrm{M}-\mathrm{N}(1)$ & $90.94(10)$ & $90.05(9)$ \\
$\mathrm{Cl}(1)-\mathrm{M}-\mathrm{N}(2)$ & $177.68(9)$ & $177.81(9)$ \\
$\mathrm{Cl}(2)-\mathrm{M}-\mathrm{N}(1)$ & $177.37(9)$ & $177.34(9)$ \\
$\mathrm{Cl}(2)-\mathrm{M}-\mathrm{N}(2)$ & $91.27(10)$ & $89.93(9)$ \\
$\mathrm{C}(5)-\mathrm{C}(11)-\mathrm{C}(6)$ & $108.5(3)$ & $112.9(3)$ \\
$\mathrm{N}(1)-\mathrm{C}(5)-\mathrm{C}(11)-\mathrm{Y}(1)^{\mathrm{a}}$ & $-176.7(3)$ & $-70.3(4)$ \\
$\mathrm{N}(2)-\mathrm{C}(6)-\mathrm{C}(11)-\mathrm{Y}(1)^{\mathrm{a}}$ & $176.1(3)$ & $68.6(4)$ \\
\hline
\end{tabular}

a) For $\mathrm{M}=\mathrm{Pt}, \mathrm{Y} 1=\mathrm{O} 1$; for $\mathrm{M}=\mathrm{Pd}, \mathrm{Y} 1=\mathrm{S} 1$. 


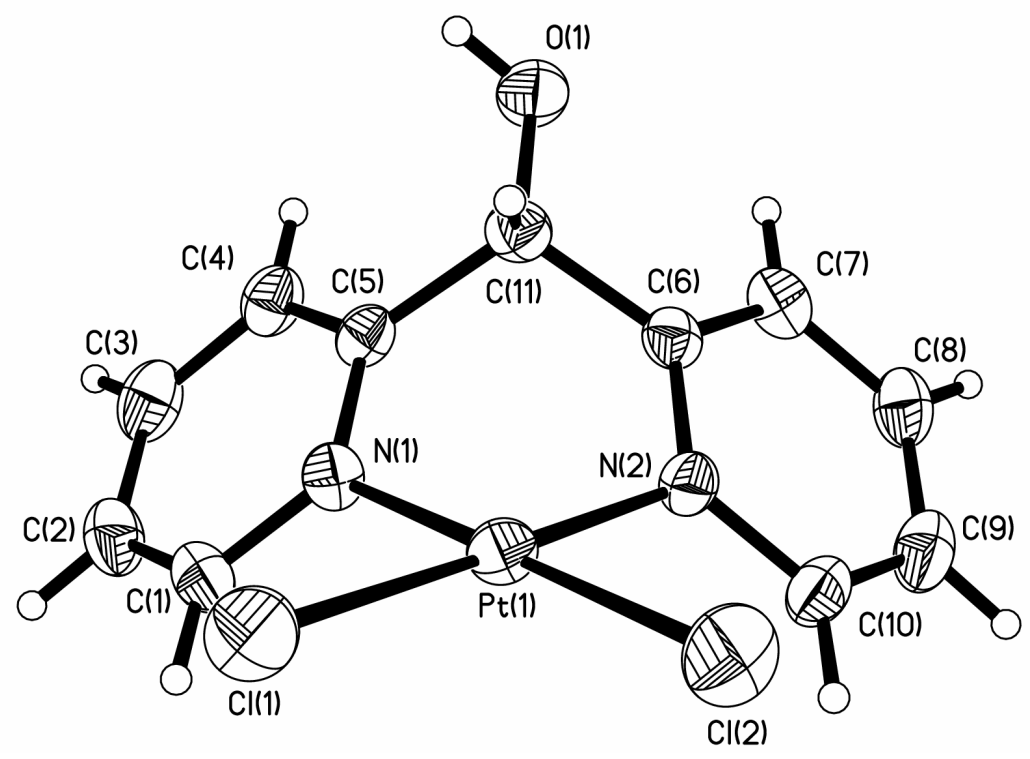

Figure 2. ORTEP diagram of 3.DMSO with labeled atoms and $40 \%$ probability displacement ellipsoids (DMSO molecule is omitted for clarity).

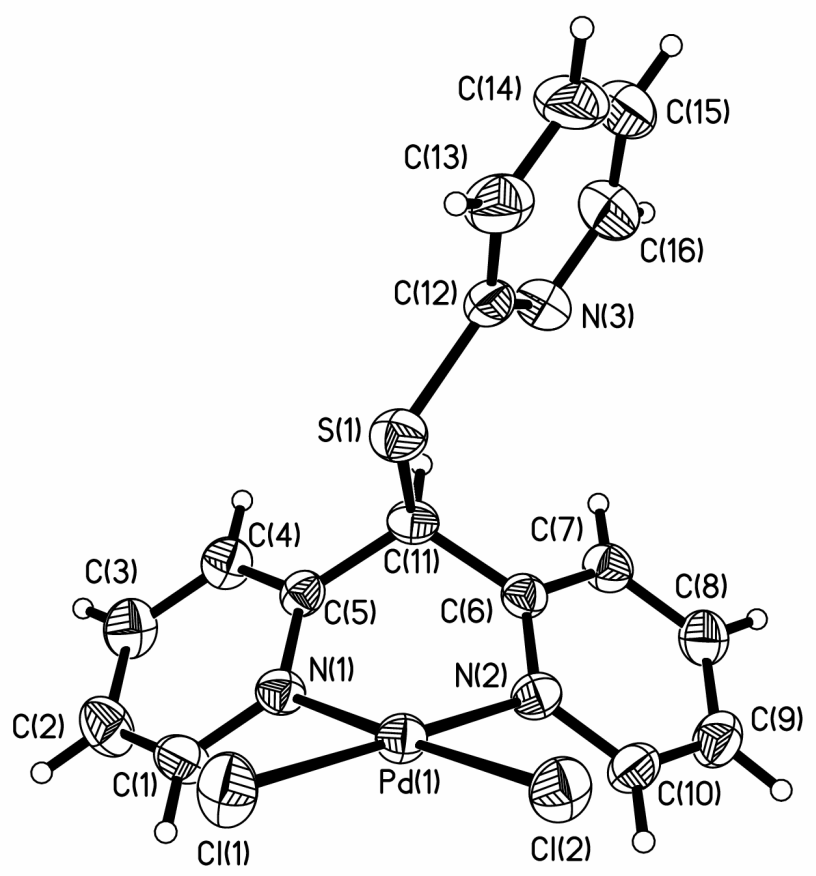

Figure 3. ORTEP diagram of $4 \cdot \mathrm{DMSO}$ with labeled atoms and $40 \%$ probability displacement ellipsoids (DMSO molecule is omitted for clarity). 


\section{Experimental Section}

General Procedures. Unless otherwise noted, all reagents used in this work are commercially available (Aldrich) and were used without further purifications. Compounds di-(2pyridyl)chloromethane and di-(2-pyridyl)hydroxymethane 1 were prepared according to the literature procedure. ${ }^{21}$ Solvents were dried and distilled by standard methods before use. Melting points were determined with a Mel-Temp II instrument and are uncorrected. Spectra were recorded with the following instruments. Elemental analyses: Perkin-Elmer Series II CHNS/O Analyzer. IR spectra: $4000-400 \mathrm{~cm}^{-1}$ range, Perkin-Elmer System 2000 FTIR spectrometer, as $\mathrm{KBr}$ pellets. Mass spectra: EI- and FAB-mass spectra: Jeol JMS-AX505HA with a Xe beam at 6 $\mathrm{keV}$, and nitrobenzylic alcohol as matrix (FAB). NMR spectra: Jeol Eclipse 400 spectrometer, residual solvent signal used as reference for ${ }^{1} \mathrm{H}$ NMR spectra; ${ }^{13} \mathrm{C}\left\{{ }^{1} \mathrm{H}\right\}$ NMR spectra referenced through the solvent peaks; chemical shifts quoted on the $\delta$ scale (downfield shifts positive) relative to tetramethylsilane $\left({ }^{1} \mathrm{H},{ }^{13} \mathrm{C}\left\{{ }^{1} \mathrm{H}\right\}\right)$; spectra recorded at about $20{ }^{\circ} \mathrm{C} ;{ }^{1} \mathrm{H}, 399.78 \mathrm{MHz}$; ${ }^{13} \mathrm{C}\left\{{ }^{1} \mathrm{H}\right\}, 100.53 \mathrm{MHz}$. Assignments of all compounds were performed by means of homonuclear correlation (cosy) and heteronuclear correlation (hetcor) experiments.

Suitable single crystals of $\mathbf{3}$ and $\mathbf{4}$ were obtained by slow evaporation of a DMSO solution in a NMR tube. X-ray diffraction data on $\mathbf{3}$ and $\mathbf{4}$ were collected at about $25^{\circ} \mathrm{C}$ with a CCD Smart 6000 diffractometer through the use of Mo-Ka radiation $(\lambda=0.71073 \AA$, graphite monochromator). Data were integrated, scaled, sorted and averaged using the SMART software package. Structures were solved by direct methods, using SHELXTL NT Version $5.10^{25}$ and refined by full-matrix least squares against $F^{2}$. An empirical absorption correction based on the multiple measurement of equivalent reflections was applied by using the program SADABS. The displacement parameters of non-hydrogen atoms were refined anisotropically. The positions of the hydrogen atoms were kept fixed with a common isotropic displacement parameter. Crystallographic data are given in Table 2.

\section{Di-(2-pyridyl)-2-pyridylsulfanylmethane (2)}

A mixture of di-(2-pyridyl)chloromethane $(200 \mathrm{mg}, 0.98 \mathrm{mmol})$ and 2-mercaptopyridine (110 $\mathrm{mg}, 0.98 \mathrm{mmol}$ ) in $20 \mathrm{~mL}$ of dry $\mathrm{CHCl}_{3}$ was refluxed for $16 \mathrm{~h}$. Removal of the solvent under vacuum was followed by addition of $20 \mathrm{~mL}$ of water and acidified with $\mathrm{HCl} 2 \mathrm{M}$ and stirred for $10 \mathrm{~min}$. The aqueous layer was neutralized with $\mathrm{K}_{2} \mathrm{CO}_{3}$ and extracted with $25 \mathrm{~mL}$ of chloroform; this solution was dried by means of a column of Celite and $\mathrm{Na}_{2} \mathrm{SO}_{4}$. The slow evaporation of the solvent yielded a brown solid. Yield: $92 \%$, $(245 \mathrm{mg})$. m. p.: $77-79^{\circ} \mathrm{C}$. - IR: $v\left(\mathrm{~cm}^{-1}\right)=1618$ $(\mathrm{C}=\mathrm{N}), 1579,1555(\mathrm{C}=\mathrm{C})$. - Anal. Calcd for $\mathrm{C}_{16} \mathrm{H}_{13} \mathrm{~N}_{3} \mathrm{~S} ; \mathrm{C}, 68.79$; H, 4.69. Found: $\mathrm{C}, 68.07, \mathrm{H}$, 4.74. EI: $\mathrm{m} / \mathrm{z} 279\left[\mathrm{M}^{+}\right]$.

\section{Cis-dichloro[di-(2-pyridyl)hydroxymethane]platinum (II) (3)}

To a solution of $\mathrm{PtCl}_{2}(250 \mathrm{mg}, 0.94 \mathrm{~mol})$ in $40 \mathrm{~mL}$ of hot acetonitrile were added $175 \mathrm{mg}(0.94$ $\mathrm{mmol}$ ) of 1 . The resulting brown solution was refluxed by $24 \mathrm{~h}$ and cooled to room temperature to give a brown suspension. The cold suspension was filtered and the yellow solid obtained was 
dried in vacuum. Yield: $86 \%(366 \mathrm{mg})$. Dec.: $275^{\circ} \mathrm{C}$. - IR: $v\left(\mathrm{~cm}^{-1}\right)=1606(\mathrm{C}=\mathrm{N}), 1565(\mathrm{C}=\mathrm{C})$. Anal. Calcd for $\mathrm{C}_{11} \mathrm{H}_{10} \mathrm{Cl}_{2} \mathrm{~N}_{2} \mathrm{OPt} \bullet\left(\mathrm{CH}_{3}\right)_{2} \mathrm{SO}$; C, 29.44; H, 3.04. Found: C, 29.32, H, 2.92. FAB+: $\mathrm{m} / \mathrm{z} 452\left[\mathrm{M}^{+}\right], 417\left[\mathrm{M}^{+}-\mathrm{Cl}\right]$.

\section{Cis-dichloro-[di-(2-pyridyl)-2-pyridylsulfanylmethane]palladium(II) (4)}

To a solution of $\mathrm{PdCl}_{2}(64 \mathrm{mg}, 0.35 \mathrm{mmol})$ in $25 \mathrm{~mL}$ of hot acetonitrile were added $100 \mathrm{mg}(0.35$ $\mathrm{mmol}$ ) of 2 . The brown solution obtained was refluxed by $24 \mathrm{~h}$ and cooled to room temperature to give a brown suspension. The cold suspension was filtered and the brown solid obtained was dried in vacuum. Yield: $90 \%(147 \mathrm{mg})$. m. p.: $243^{\circ} \mathrm{C}$. - IR: $v\left(\mathrm{~cm}^{-1}\right)=1602,1576,1565(\mathrm{C}=\mathrm{C})$. Anal. Calcd for $\mathrm{C}_{16} \mathrm{H}_{13} \mathrm{Cl}_{2} \mathrm{~N}_{3} \mathrm{SPd} \bullet\left(\mathrm{CH}_{3}\right)_{2} \mathrm{SO}$; C, 40.42; H, 3.58. Found: C, 41.00, H, 3.23. FAB+: $\mathrm{m} / \mathrm{z} 522\left[\mathrm{M}^{+}-\mathrm{Cl}\right]$.

\section{Cis-dichloro-[di-(2-pyridyl)- 2-pyridylsulfanylmethane]platinum(II) (5)}

Complex 5 was prepared using the method described for the formation of the complexes $\mathbf{3}$ and $\mathbf{4}$, with $\mathrm{PtCl}_{2}(95 \mathrm{mg}, 0.35 \mathrm{~mol})$ and $100 \mathrm{mg}(0.35 \mathrm{mmol})$ of 2 in $25 \mathrm{~mL}$ of acetonitrile. 5 Was obtained as a yellow solid. Yield: $85 \%(166 \mathrm{mg})$. Dec.: $253^{\circ} \mathrm{C}$. - IR: $v\left(\mathrm{~cm}^{-1}\right)=1590,1571$ $(\mathrm{C}=\mathrm{C}) . \mathrm{FAB}+: \mathrm{m} / \mathrm{z} 545\left[\mathrm{M}^{+}\right], 510\left[\mathrm{M}^{+}-\mathrm{Cl}\right]$.

\section{Supplementary Information Available}

Supplementary data are available from the Cambridge Crystallographic Data Centre, with the deposition numbers CCDC649169 (3) and CCDC649168 (4). Copies of this information are available free of charge from the Director, CCDC, 12 Union Road, Cambridge, CB2 1EZ, UK (Fax: +44 1223336 033; e-mail: deposit@ccdc.cam.ac.uk or http://www.ccdc.cam.ac.uk).

\section{Acknowledgements}

A.J.P. fully acknowledges to CONACyT (44009) the scholarship for supporting their studies. We wish to thank Dra. Verónica García Montalvo (UNAM) for the mass spectra and Mrs. Yolanda Marmolejo (UAEH) for the vibrational spectra and elemental analyses.

\section{References}

1. Vedernikov, A. N.; Fettinger, J. C.; Mohr, F. J. Am. Chem. Soc. 2004, 126, 11160.

2. Steel, J.; Sumby, C. J. Dalton Trans. 2003, 4505.

3. Katsoulakou, E.; Lalioti, N.; Raptopoulou, C. P.; Terzis, A.; Manessi-Zoupa, E.; Perlepes, S. P. Inorg. Chem. Commun. 2002, 719.

4. Schareina, T.; Hillebrand, G.; Fuhrmann, H.; Kempe, R. Eur. J. Inorg. Chem. 2001, 2421. 
5. Carr, J. D.; Coles, S. J.; Hursthouse, M. B.; Light, M. E.; Munro, E. L.; Tucker, J. H. R.; Westwood, J. Organometallics 2000, 19, 3312.

6. Bernhard, P. V.; Comba, P.; Mahu-Rickenbach, A.; Stebler, S.; Steiner, S.; Várnagy, K.; Zehnder, M. Inorg. Chem. 1992, 31, 4194.

7. Godard, C.; Duckett, S. B.; Parsons, S.; Perutz, R. N. Chem. Comm. 2003, 18, 2332.

8. Milani, B.; Mestroni, G.; Zangrando, E. Croat. Chem. Acta 2001, 4, 851.

9. Garcia, A. M.; Manssur, J. Acta Crystallogr., Sect. C. 1994, 1882.

10. Gornitzka, H.; Stalke, D. Organometallics 1994, 13, 4398.

11. Crowder, K. N.; Garcia, S. J.; Burr, R. L.; North, J. M.; Wilson, M. H.; Conley, B. L.; Fanwick, P. E.; White, P. S.; Sienerth, K. D.; Granger, R. M. Inorg. Chem. 2004, 43, 72.

12. Wen-Rui, Y.; Ze-Hua, L.; Qian-Feng Z. Acta Cryst. 2003, C59, m139.

13. Kin-Ying, H.; Wing-Yiu, Y.; Kung-Kai, C.; Chi-Ming, C. Chem. Commun. 1998, 2101.

14. Mock, C.; Puscasu, I.; Rauterkus, M. J.; Tallen, G.; Wolf, J. E. A.; Krebs, B. Inorg. Chim. Acta 2001, 319, 109.

15. Bakir, M.; Brown, O. J. Mol. Struct. 2002, 641, 183.

16. Silberg, J.; Schareina, T.; Kempe, R.; Wurst K.; Buchmeiser, M. R. J. Organomet. Chem. 2001, 622, 6 .

17. Grewe, J; Hagenbach, A.; Stromburg, B.; Alberto, R.; Vazquez-Lopez, E.; Abram, U. Z. Anorg. Allg. Chem. 2003, 629, 303.

18. Canty, A. J.; Chaichit, N.; Gatehouse, B. M., George, E. E.; Hayhurst, G. Inorg. Chem. 1981, $20,2414$.

19. Flores-Chávez, B.; Martínez-Ortega, B. A.; Alvarado-Rodríguez, J.G.; Andrade-López, N. J. Chem. Crystallogr. 2005, 35, 435.

20. Andrade-López, N.; Alvarado-Rodríguez, J. G.; González-Montiel, S.; Rodríguez-Méndez, M. G.; Hernández-Páez, M. E.; Galán-Vidal, C. A. doi:10.1016/j.poly.2007.06.006.

21. La Crois, R. Ph. D. thesis, University Library of Groningen, Netherlands, 2002.

22. Annibale, G.; Canovese, L.; Cattalini, L.; Natile, G.; Biagini-Cingi, M.; Manotti-Lanfredi, A.-M.; Tiripicchio, A. J. Chem. Soc., Dalton Trans. 1981, 2280.

23. Canty, A: J.; Minchin, N. J.; Engelhardt, L. M.; Skelton, B. W.; White, A. H. J. Chem. Soc. Dalton Trans. 1986, 645.

24. Porterfield, W. W., Inorganic Chemistry: A Unified Approach, 2nd ed., Academic Press, Inc. USA, 1993, 214.

25. SHELXTL 5.10 Bruker AXS, Inc., Madison, WI, USA, 1998. 